\title{
Impacts of ammonium nitrate on survival of tadpoles of the common skittering frog (Euphlyctis cyanophlyctis)
}

\author{
Rukhsana Bibi, Muhammad Rais*, Muhammad Saeed, Ayesha Akram, Tariq Mahmood, \\ Maqsood Anwar
}

Department of Wildlife Management, Faculty of Forestry, Range Management and Wildlife, Pir Mehr Ali Shah, Arid Agriculture University, Rawalpindi 46000, Pakistan.

*Correspondence: Phone: +92-051-9292121, Fax: +92-051-9292121, E-mail: sahil@uaar.edu.pk

Received: 13 November 2015; returned for review: 21 January 2016; accepted: 15 November 2016.

Amphibians are sensitive to agricultural chemicals such as pesticides and fertilizers. Data on responses of anuran species commonly found in agricultural areas of Pakistan to chemical pollution are lacking. We studied the effects of ammonium nitrate on survival of tadpoles of common skittering frog (Euphlyctis cyanophlyctis). Tadpoles were collected from seasonal shallow water ponds formed during rainy season in the vicinities of Rawalpindi and Islamabad cities. Tadpoles were treated with ammonium nitrate at either 62.5, 125, 250, 500 or $1000 \mathrm{mg}$ nitrate / 1, and compared with a control group. Individual survival was significantly affected by increased ammonium nitrate treatments $(P<0.05)$, with survival rates after 18 days of exposure ranging from $83 \%$ at 62.5 $\mathrm{mg} \mathrm{NO}{ }^{-} / 1$ to complete mortality at the highest ammonium nitrate concentration. The logistic regression model with individual survival as a binomial outcome variable and fertilizer concentration as independent variable explained $87 \%$ of the variance in survivorship (Nagelkerke $\mathrm{R}^{2}$ ), and correctly classified $94.0 \%$ of the cases $\left(\chi^{2}=259,5\right.$ d.f., $\left.P<0.0005\right)$. Our lab-based findings suggest that ammonium nitrate at high concentrations may affect anuran species of Pakistan in croplands with extensive nitrogen-based fertilizer use.

Key words: ammonium nitrate; Dicroglossidae; regression; survivorship; tadpoles.

Impacto del nitrato amónico sobre la supervivencia de las larvas de Euphlyctis cyanophlyctis. Los anfibios son sensibles a los efectos de algunos agroquímicos como plaguicidas y fertilizantes. Investigamos los efectos del nitrato amónico sobre la supervivencia de las larvas de Euphlyctis cyanophlyctis. Colectamos los renacuajos de charcas someras estacionales que se forman durante la estación lluviosa en las proximidades de las ciudades de Rawalpindi e Islamabad. Los renacuajos se trataron con nitrato amónico a un de las siguientes concentraciones: 62,5, 125, 250, 500 ó 1000 mg nitrato / 1 , comparando además con un grupo control. La supervivencia de los individuos se vio afectada de manera significativa por el incremento en las concentraciones de nitrato amónico $(P<0,05)$, con tasas de supervivencia que tras 18 días de exposición variaron entre el 83\% a 62,5 mg $\mathrm{NO}_{3}^{-} / 1$ hasta la mortalidad total en la concentración más elevada de nitrato amónico. El modelo de regresión logística con la mortalidad de los individuos como respuesta binomial y la concentración de fertilizante como variable independiente explicó el $87 \%$ de la varianza de la supervivencia ( $\mathrm{R}^{2} \mathrm{Na}-$ gelkerke), clasificando correctamente un $94 \%$ de los casos $\left(\chi^{2}=259,5\right.$ g.l., $\left.P<0.0005\right)$. Nuestras observaciones en el laboratorio sugieren que las elevadas concentraciones de nitrato amónico po- 
drían afectar a las especies de anuros paquistaníes que habitan en zonas agrícolas sometidas a una aplicación intensiva de fertilizantes .

Key words: bioacumulación de metales; contaminación; Dicroglossidae; histología; histopatología.

Amphibians have a great significance in ecotoxicological studies, as their naked, permeable skins make them very susceptible to the uptake of anthropogenic chemicals and contaminants in the environment (Blaustein et al., 2003). Amphibian populations are declining worldwide; it is estimated that $30 \%$ (1895 out of 6285 ) of the amphibians which conservation status has been assessed by the International Union for Conservation of Nature are threatened (IUCN, 2016). Scientists believe that a multitude of interrelated factors are responsible for this decline (Alford \& Richards, 1999), including climate change, increased exposure to ultraviolet radiation, emergent pathogens, introduced species, habitat destruction, acid rain and agricultural chemicals such as pesticides and fertilizers (Blaustein et al., 2003; Boone \& Bridges, 2003). Actually, the leading role played by agrochemicals on decline of certain amphibian populations has already been demonstrated (DAvidson, 2004).

Nitrogen-based fertilizers are believed to impact amphibian populations in agricultural areas (Oldham et al., 1997; GriffisKyle, 2005). Numerous laboratory studies have shown that ammonium nitrate, one of the world's leading nitrogenous fertilizers, can significantly reduce larval survivorship in many species of frogs and toads (Burgett et al., 2007). Long term exposure to ammonium and nitrate resulting from the dissociation of this compound in the water is known to alter developmental and behavioural functions of anurans (HECNAR, 1995). Some morphological abnormalities have also been reported in ammonium nitrate-treated tadpoles of species like Bufo calamita, Bufo spinosus and Discoglossus galganoi (OrTiz et al., 2004). Malformed individuals are more susceptible to predation, have low reproductive success, weak immune system and endocrine system (Bridges, 1997, 1999a,b, 2000; Ouellet et al., 1997; Boone \& Semlitsch, 2002), all of which considerably reduces their survival chances in the wild.

Ecotoxicological information regarding amphibians from Pakistan is very scarce. Only a few studies about the effects of various pesticides on certain enzymes of adult frogs are available from this country. Pyrethroid, organophosphate and organochlorine pesticides decreased concentrations of enzymes like cholinesterase and alkaline phosphatase in liver, kidney and brain of the common skittering frog (Euphlyctis cyanophlyctis) and the bullfrog (Hoplobatrachus tigerinus) (KHAN et al., 2006, 2007, 2008; Khan \& Yasmeen, 2008). However, studies reporting the impacts of fertilizers on amphibians from Pakistan are not available. We conducted the present study to investigate if tadpole survivorship in $E$. cyanophlyctis, one of the most common amphibians in croplands from Pakistan, was affected by the widely used nitrogenous fertilizer ammonium nitrate. 


\section{Materials and Methods}

We carried out the present study in areas of Rawalpindi and Islamabad. The humid subtropical climate prevails in the area, with generally long and very hot summers followed by a monsoon season and mild wet winters. The area features hard substrate and scrub vegetation in most parts. The permanent wetlands of the area include rivers Korang and Soan, and water storage reservoirs such as Rawal Dam, Simly Dam and several other small dams with associated marshes (CHAUdHRY \& Rasul, 2004; Ashraf et al., 2007). Numerous ephemeral ponds and pools are formed during the monsoon season (JulyAugust), during which the breeding activity of anurans reaches its peak. The area possesses few common, non-endangered toad and frog species such as the southeast Asian toad (Duttaphrynus melanostictus), the Indus valley toad (Duttaphrynus stomaticus), the ant frog (Microhyla ornata), E. cyanophlyctis and H. tigerinus (RAIs et al., 2012).

We selected E. cyanophlyctis as model species because it prefers shallow water ponds and edges of other water bodies, is highly aquatic, is the most common frog species in the area, and is also associated with croplands in the plains of Pakistan (KHAN, 2006). No permit is required to collect or dissect this species since it is not included in the applicable catalogues of protected species, i.e. Punjab Wildlife Acts and Rule (1974) and Islamabad Wildlife Protection, Preservation, Conservation and Management Ordinance (1979).

We collected E. cyanophlyctis tadpoles $(\mathrm{N}>200)$ at developmental stage 25
(GosNer, 1960) from Rawal Lake Spillway Area (UTM WGS84 coordinates, zone 43: $X$ $=342226.7, \mathrm{Y}=3740053.9)$ and Loi Bher Wildlife Park ( $X=348616.5, Y=3737423.8$ ); these are non-agricultural areas, which minimized the risk of tadpoles having been exposed to ammonium nitrate prior collection. Tadpoles were collected using dip nets and transferred into buckets filled with water from the same pond. We carried out buckets to the laboratory at the Department of Wildlife Management, Pir Mehr Ali Shah, Arid Agriculture University Rawalpindi, and kept tadpoles for 24 hours in glass aquaria $\left(0.12 \mathrm{~m}^{3}\right)$ with water filtering and aeration units.

Ammonium nitrate solutions were prepared from granular ammonium nitrate. Data on ecologically relevant concentrations of this fertilizer in the study area are not available, but published literature $\left(\mathrm{X}_{\mathrm{U}}\right.$ \& Oldham, 1997; Rouse et al.,1999; OrtizSANTALiestra et al. 2006) have reported concentrations of ammonium or nitrate corresponding to 10 to $258 \mathrm{mg} / 1$ ammonium nitrate to be ecologically relevant for amphibians elsewhere. We prepared five nominal concentrations of ammonium nitrate: 1000, 500, 250, 125 and $62.5 \mathrm{mg}$ ammonium nitrate / 1 . A $20 \mathrm{~g} / 1$ stock solution was prepared in distilled water. To prepare the different experimental concentrations, volumes of 200, 100, 50, 25 and 12.5 $\mathrm{ml}$ of the stock solution were added to 41 of tap water, respectively. Each concentration was replicated thrice, with a batch of 10 tadpoles (2.5 tadpoles per litre) in each replicate. Three additional batches with 10 untreated tadpoles each were used as controls. To control for the presence of excess unionized ammonia, initial $\mathrm{pH}$ was meas- 
Table 1: Results of the repeated measures analysis of the variance to test the evolution over time of ammonium nitrate effects on Euphlyctis cyanophlyctis tadpole survival .

\begin{tabular}{cccccc}
\hline Test & Source of variation & Sum of squares & d.f. & F & $\boldsymbol{P}$ \\
\hline \multirow{2}{*}{ Within-subject } & Time & 10.911 & 1 & 56.999 & $<0.001$ \\
effects & Concentration*Time & 7.877 & 5 & 8.229 & 0.001 \\
& Error & 2.297 & 12 & & \\
Between- & Intersection & 122.881 & 1 & 209.419 & $<0.001$ \\
subject effects & Concentration & 70.701 & 5 & 24.098 & $<0.001$ \\
& Error & 7.041 & 12 & & \\
\hline
\end{tabular}

ured in aquaria and found to range from 7.37 to 7.41 . The water was not renewed for the entire duration of the experiment, which lasted 18 days; this means that actual ammonium and nitrate concentrations were expected to significantly decrease over time throughout the experiment (Hatch \& Blaustein, 2003), although Marco et al. (1999) did not detect significant variation in nitrate levels after 7 days in experimental aquaria. All reference to experimental levels in the present paper refers to nominal values. The tadpoles were fed with boiled chopped cabbage, fish meal and boil chicken flakes.

Tadpole survivorship was calculated daily as number of surviving tadpoles at that specific day of experiment divided by the initial number of tadpoles. Daily mortality rates were arcsine of square root transformed to fit a normal distribution of residuals. Evolution of daily mortality rates during the experiment was analysed using a repeated measures analysis of the variance (ANOVA), with the ammonium nitrate concentration as fixed factor. Treatments causing significant mortality were identified through Tukey post-hoc tests run after ANOVAs for inter-treatment comparisons conducted with data of each specific day of experiment. A logistic regression was performed to ascertain the effects of ammonium nitrate concentrations on the likelihood of tadpoles to survive.

\section{Results}

Repeated measures ANOVA showed that tadpole survival significantly decreased over time as ammonium nitrate concentration increased (Table 1). Significant mortality was detected from day 2 of experiment $\left(\mathrm{F}_{5,12}=15.827 ; P<0.001\right)$, when all tadpoles exposed to the highest concentration had died. Survival of tadpoles exposed to $500 \mathrm{mg} / 1$ ammonium nitrate was significantly lower than that of controls after day 7 of experiment $\left(\mathrm{F}_{5,12}=13.132 ; P<\right.$ $0.001)$. From day 8 of experiment onwards, we also observed reduced survival compared to controls among tadpoles exposed to 250 and $100 \mathrm{mg} / 1\left(\mathrm{~F}_{5,12}=12.704 ; P<\right.$ 0.001). The lowest ammonium nitrate tested concentration did not significantly affect survival (Fig. 1). The logistic regression (Nagelkerke $R^{2}$ ) explained $87 \%$ of the variance in the survivorship and correctly classified $94 \%$ of cases. The model was statistically significant $\left(\chi^{2}=259,5\right.$ d.f., $P<$ 0.0005). 


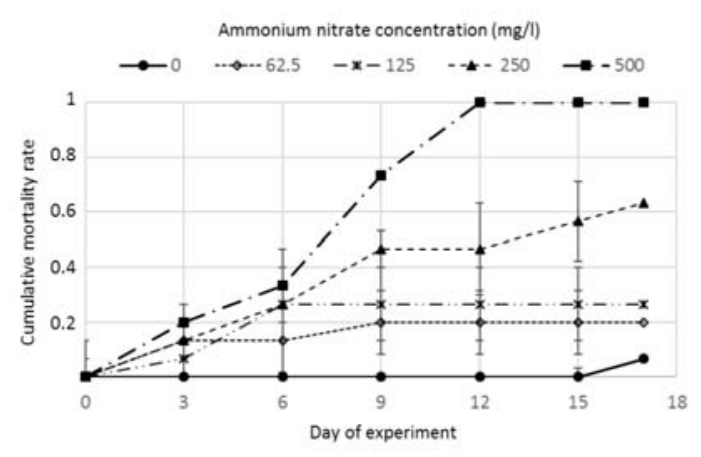

Figure 1: Evolution during the experiment of cumulative mortality rates (mean \pm standard error) of Euphlyctis cyanophlyctis tadpoles exposed to different ammonium nitrate concentrations. Data corresponding to the 1000 mg / 1 treatment are not shown as $100 \%$ mortality was observed at day 2 of experiment.

\section{Discussion}

The present study reveals that increasing ammonium nitrate concentrations reduce survival of E. cyanophlyctis tadpoles. Amphibian eggs and larvae living in agricultural regions are impacted by ammonium nitrate pollution originated from the use of this substance as fertilizer (Rouse et al., 1999), and several studies have provided evidence of the lethal effect of this chemical on amphibian aquatic stages. HeCNAR (1995) reported that fertilizers and other chemicals used in agriculture are severe threats to amphibian populations after observing mortality of tadpoles of American toad (Anaxyrus americanus), chorus frog (Pseudacris triseriata), northern leopard frog (Lithobates pipiens) and green frog (Lithobates clamitans) exposed to ammonium nitrate at concentrations between 77.71 and $224.57 \mathrm{mg} \mathrm{NO}_{3} \mathrm{NH}_{4} /$ 1. After long-term exposures, survival of $P$. triseriata and L. pipiens was significantly reduced also at $57.14 \mathrm{mg} \mathrm{NO}_{3} \mathrm{~N} / \mathrm{l}$. OrtizSANTAliestra et al. (2006) concluded that environmentally relevant levels of ammonium nitrate could induce mortality and might affect population dynamics of several amphibian species in agricultural environments. BurgetT et al. (2007) reported that ammonium nitrate at concentrations above $50 \mathrm{mg} / 1$ (lower than the lowest used in the present study) decreased survivorship of wood frog (Lithobates sylvaticus) tadpoles. Oromi et al. (2009) suggested that if the levels of nitrate in water surpassed $100 \mathrm{mg} / \mathrm{l}$ (corresponding to $129 \mathrm{mg}$ $\mathrm{NO}_{3} \mathrm{NH}_{4} / 1$ ), the survival probabilities of the European common frog (Rana temporaria) larvae might be reduced. The results of the present study are in accordance with the aforementioned findings on ammonium nitrate-associated lethality.

Besides lethal effects, ammonium nitrate has been suggested to alter amphibian endocrine system, affecting development and other functions (GuILlETte \& EdwARDs, 2005; EdwARds et al., 2006; ORTON et al., 2006), and also to affect central nervous system and impair anti-predatory ability of tadpoles (OrTIZ-SANTALIESTRA et al., 2010). Although we did not analyse sublethal effects because of the high mortality recorded in almost all tested ammonium nitrate concentrations, the potential of these sublethal effects occurring at lower concentrations to affect larval survival probabilities in the wild needs further investigation.

Common skittering frog (E. cyanophlyctis) is one of the most common frogs in Pakistan, and is abundant also in agricultural areas. Our lab-based findings suggest that ammonium nitrate in high con- 
centrations might affect this anuran species in croplands with extensive nitrogenbased fertilizer use. We must notice that tadpoles were exposed to a single pulse of ammonium nitrate, resembling what can happen in the wild after runoff or wash of applied fertilizers towards to the breeding ponds. Since amphibians breed in water, ammonium and nitrate occurring when ammonium nitrate is dissolved may get absorbed by anuran eggs and permeable skin of tadpoles and adults, or may enter into their bodies directly by oral water uptake. The results of the present paper enhance the necessity of recommending that detailed studies are carried out on the monitoring of ammonium nitrate levels in Pakistan's croplands, and that field data are collected to understand how pollution by nitrogenous fertilizers affect anurans in croplands of the country.

\section{REFERENCES}

Alford, R.A. \& Richards, S.J. (1999). Global amphibian declines: a problem in applied ecology. Annual Review of Ecology and Systematics 30: 133-165.

Ashraf, M.; Kahlown, M.A. \& AshfaQ, A. (2007). Impact of small dams on agriculture and groundwater development: a case study from Pakistan. Agricultural Water Management 92: 90-98.

Blaustein, A.R.; Romansic, J.M.; Kiesecker, J.M. \& НАтсн, A.C. (2003). Ultraviolet radiation, toxic chemicals and amphibian population declines. Diversity and Distributions 9: $123-140$

Boone, M. \& BRIDges, C.M. (2003). Effects of pesticides on amphibian populations, In R.D. Semlitsch \& D.B. Wake (eds.) Amphibian Conservation. Smithsonian Institution, Washington, DC, USA, pp. 152-167.

Boone, M.D. \& SemLitsch, R.D. (2002). Interac- tions of an insecticide with competition and pond drying in amphibian communities. Ecological Applications 12: 307-316.

Bridges, C.M. (1997). Tadpole swimming performance and activity affected by acute exposure to sublethal levels of carbaryl. Environmental Toxicology and Chemistry 16: 1935-1939.

BRIDGes, C.M. (1999a). Effects of a pesticide on tadpole activity and predator avoidance behavior. Journal of Herpetology 33: 303306.

Bridges, C.M. (1999b). Predator-prey interactions between two amphibian species: effects of insecticide exposure. Aquatic Ecology 33: 205-211.

BRIDGes, C.M. (2000). Long-term effects of pesticide exposure at various life stages of the southern leopard frog (Rana sphenocephala). Archives of Environmental Contamination and Toxicology 39: 91-96.

Burgett, A.; Wright, C.D.; SMith, G.R.; ForTUNE, D.T. \& JoHnSON, S.L. (2007). Impact of ammonium nitrate on wood frog (Rana sylvatica) tadpoles: Effects on survivorship and behavior. Herpetological Conservation and Biology 2: 29-34.

Chaudhry, Q.Z. \& Rasul, G. (2004). Agroclimatic classification of Pakistan. Science Vision 9: 59-66.

Davidson, C. (2004). Declining downwind: amphibian population declines in California and historical pesticide use. Ecological Applications 14: 1892-1902.

Edwards, T.M.; McCoy, K.A.; Barbeau, T.; McCoy, M.W.; Thro, J.M. \& Guillette, L.J., JR. (2006). Environmental context determines nitrate toxicity in southern toad (Bufo terrestris) tadpoles. Aquatic Toxicology 78: 50-58.

Gosner, K.L. (1960). A simplified table for staging anuran embryos and larvae with notes on identification. Herpetologica 16: 183-190.

Griffis-Kyle, K.L. (2005) Ontogenic delays in effects of nitrite exposure on tiger salamanders (Ambystoma tigrinum tigrinum) 
and wood frogs (Rana sylvatica). Environmental Toxicology and Chemistry 24: 15231527.

Guillette, L.J., JR. \& Edwards, T.M. (2005). Is nitrate an ecologically relevant endocrine disruptor in vertebrates? Integrative and Comparative Biology 45: 19-27.

НатсH, A.C. \& Blaustein A.R. (2003). Combined effects of UV-B radiation and nitrate fertilizer on larval amphibians. Ecological Applications 13: 1083-1093.

Hecnar, S.J. (1995). Acute and chronic toxicity of ammonium nitrate fertilizer to amphibians from southern Ontario. Environmental Toxicology and Chemistry 14: 2131-2137.

IUCN (2016). The IUCN Red List of Threatened Species, v. 2016-2. International Union for Conservation of Nature and Natural Resources, Gland, Switzerland. Available at http://www.iucnredlist.org/. Retrieved on 15 November 2016.

Khan, M.Z. (2006). Amphibians and Reptiles of Pakistan. Krieger Publishing Company, Malabar, Florida, USA.

Khan, M.Z. \& YAsmeen, G. (2008). Effect of sandaphos and $\beta$-cypermethrin exposure on cholinesterase and alkaline phosphatase activity in liver, kidney and brain of Euphlyctis cyanophlyctis. Canadian Journal of Pure and Applied Sciences 2: 511-519.

Khan, M.Z.; Yasmeen, G. \& Hamid, S. (2006). Effect of the sandaphos (organophosphate) and b-cypermethrin (synthetic pyrethroid) on cholinesterase activity in liver and kidney of Euphlyctis cyanophlyctis. Hamadryad 30: 176-180.

Khan, M.Z.; Rais, M. \& Yasmeen, G. (2007). Inhibitory effects on cholinesterase activity produced by the two different pesticides on brain, liver and kidney of Euphlyctis cyanophlyctis. Journal of Experimental Zoology India 10: 89-93.

Khan, M.Z.; Yasmeen, G.; Naqvi, S.N.H. \& Perveen, A. (2008). Activity of cholinesterase and alkaline phosphatase in liver, kidney and brain of Euphlyctis cyanophlyctis under the effect of chlorpyrifos and dathrin. Canadian Journal of Pure and Applied Sciences 2: 349-356.

Marco, A.; Quilchano, C. \& Blaustein, A.R. (1999). Sensitivity to nitrate and nitrite in pond-breeding amphibians from the Pacific Northwest, USA. Environmental Toxicology and Chemistry 18: 2836-2839.

Oldham, R.S.; Latham, D.M.; Hilton-Brown, D.; Towns, M.; Cooke, A.S. \& Burn, A. (1997). The effect of ammonium nitrate fertiliser on frog (Rana temporaria) survival. Agriculture, Ecosystems and Environment 61: 69-74.

Oromi, N.; Sanuy, D. \& Vilches, M. (2009). Effects of nitrate and ammonium on larvae of Rana temporaria from the Pyrenees. Bulletin of Environmental Contamination and Toxicology 82: 534-537.

Ortiz, M.E.; Marco, A.; Saiz, N.I. \& Lizana, M. (2004). Impact of ammonium nitrate on growth and survival of six European amphibians. Archives of Environmental Contamination and Toxicology 47: 234-239.

Ortiz-Santaliestra, M.E.; Marco, A.; FernánDEZ, M.J. \& LizAnA, M. (2006). Influence of developmental stage on sensitivity to ammonium nitrate of aquatic stages of amphibians. Environmental Toxicology and Chemistry 25: 105-111.

Ortiz-Santaliestra, M.E.; FernándezBenéitez, M.J.; Marco, A. \& Lizana, M. (2010). Influence of ammonium nitrate on larval anti-predatory responses of two amphibian species. Aquatic Toxicology 99: 198204.

Orton, F.; Carr, J.A. \& Handy, R.D. (2006). Effects of nitrate and atrazine on larval development and sexual differentiation in the northern leopard frog Rana pipiens. Environmental Toxicology and Chemistry 25: 65-71.

Ouellet, M.; Bonin, J.; Rodrigue, J.; DesGrangES, J. \& LAIR, S. (1997). Hindlimb deformities (ectromelia, ectrodactyly) in free-living anurans from agricultural habitats. Journal of Wildlife Diseases 33: 95-104. 
Rais, M.; Baloch, S.; Rehman, J.; Anwar, M.; Hussain, I. \& Mahmood, T. (2012). Diversity and conservation of amphibians and reptiles in North Punjab, Pakistan. Herpetological Bulletin 122: 16-25.

Rouse, J.D.; Bishop, C.A. \& Struger, J. (1999). Nitrogen pollution: an assessment of its threat to amphibian survival. Environmental Health Perspectives 107: 799-803.

Xu, Q. \& Oldham, R.S. (1997). Lethal and sublethal effects of nitrogen fertilizer ammonium nitrate on common toad (Bufo bufo) tadpoles. Archives of Environmental Contamination and Toxicology 32: 298-303. 